\title{
Tailored Cyclodextrin Pore Blocker Protects Mammalian Cells from Clostridium difficile Binary Toxin CDT
}

\author{
Maurice Roeder ${ }^{1}$, Ekaterina M. Nestorovich ${ }^{2}$, Vladimir A. Karginov ${ }^{3}$, Carsten Schwan ${ }^{4}$, \\ Klaus Aktories ${ }^{4}$ and Holger Barth ${ }^{1}{ }^{*}$ \\ 1 Institute of Pharmacology and Toxicology, University of Ulm Medical Center, \\ Albert-Einstein-Allee 11, 89081 Ulm, Germany; E-Mail: maurice.roeder@uni-ulm.de \\ 2 Department of Biology, the Catholic University of America, Washington, DC 20064, USA; \\ E-Mail: nestorovich@cua.edu \\ 3 Innovative Biologics, Inc., 13455 Sunrise Valley Dr., Suite 200, Herndon, VA 20171, USA; \\ E-Mail:vak@innovbio.com \\ 4 Institute of Experimental and Clinical Pharmacology and Toxicology, University of Freiburg, \\ 79104 Freiburg, Germany; E-Mails: carsten.schwan@ pharmakol.uni-freiburg.de (C.S.); \\ klaus.aktories@pharmakol.uni-freiburg.de (K.A.) \\ * Author to whom correspondence should be addressed; E-Mail: holger.barth@uni-ulm.de; \\ Tel.: +49-731-500-65503; Fax: +49-731-500-65502.
}

Received: 28 May 2014; in revised form: 16 June 2014 / Accepted: 27 June 2014 /

Published: 15 July 2014

\begin{abstract}
Some Clostridium difficile strains produce, in addition to toxins A and B, the binary toxin Clostridium difficile transferase (CDT), which ADP-ribosylates actin and may contribute to the hypervirulence of these strains. The separate binding and translocation component $\mathrm{CDTb}$ mediates transport of the enzyme component CDTa into mammalian target cells. CDTb binds to its receptor on the cell surface, CDTa assembles and $\mathrm{CDTb} / \mathrm{CDTa}$ complexes are internalised. In acidic endosomes, CDTb mediates the delivery of CDTa into the cytosol, most likely by forming a translocation pore in endosomal membranes. We demonstrate that a seven-fold symmetrical positively charged $\beta$-cyclodextrin derivative, per-6-S-(3-aminomethyl)benzylthio- $\beta$-cyclodextrin, which was developed earlier as a potent inhibitor of the translocation pores of related binary toxins of Bacillus anthracis, Clostridium botulinum and Clostridium perfringens, protects cells from intoxication with CDT. The pore blocker did not interfere with the CDTa-catalyzed ADP-ribosylation of actin or toxin binding to Vero cells but inhibited the $\mathrm{pH}$-dependent membrane translocation of CDTa into the cytosol. In conclusion, the cationic
\end{abstract}


$\beta$-cyclodextrin could serve as the lead compound in a development of novel pharmacological strategies against the CDT-producing strains of $C$. difficile.

Keywords: cellular uptake; Clostridium difficile CDT; binary toxin; membrane transport; translocation pore; pore blocker; $\beta$-cyclodextrin

\section{Introduction}

Clostridium difficile (C. difficile) causes enteric diseases in patients treated with broad-spectrum antibiotics that range from diarrhea to severe, potentially life-threatening pseudomembranous colitis because disturbance of the gut flora enables spore germination and growth of this pathogen [1]. The causative agents of $C$. difficile-associated diseases are the exotoxins A (TcdA, $308 \mathrm{kDa}$ ) and B (TcdB, $270 \mathrm{kDa})$, which catalyse the glucosylation of Rho, Rac and Cdc42 in the cytosol of cells thereby inhibiting signal transduction via these GTPases [2,3]. This action leads to destruction of the actin cytoskeleton, cell rounding and loss of integrity of the intestinal wall (for review see [4]). In addition to toxins $\mathrm{A}$ and $\mathrm{B}$, about $6 \%-35 \%$ of the strains produce the binary actin ADP-ribosylating toxin CDT [5-7], which directly attacks the actin cytoskeleton and contributes to the hypervirulence of these strains with associated increased patients morbidity and mortality [7-13]. Like the other members of the clostridial binary actin-ADP-ribosylating toxins family, C. botulinum C2 toxin [14-16], C. perfringens iota toxin [17-20], and C. spiroforme transferase (CST) [21], CDT consists of two non-linked proteins, which must assemble on the surface of target cells to exhibit their cytotoxic effects (for review see [22,23]). The binding/translocation component CDTb binds to lipolysis stimulated receptor (LSR), which is the protein receptor for CDT, CST and iota toxin [24,25] and induces clustering of LSR in lipid rafts [26]. Besides LSR, CD44 is involved in binding of CDT and the other iota-like toxins to target cells and might serve as a co-receptor [27]. After uptake of the $\mathrm{CDTb} / \mathrm{CDTa}$ complexes by receptor-mediated endocytosis, CDTa translocates from acidified endosomes into the cytosol [28] to ADP-ribosylate G-actin [5,29]. The molecular and cellular consequences following toxin-catalysed mono-ADP-ribosylation of actin at arginine-177 were described in detail for the related $\mathrm{C} 2$ and iota toxins [14,30-37]. Taken together, this modification inhibits actin polymerization [38] and causes cell-rounding. Moreover, it also affects the microtubules, which form long protrusions around the cell body and in the case of CDT it was shown that these protrusions bind $C$. difficile and increase its adherence to enterocytes [39,40].

We provided evidence that the transport of CDTa across endosomal membranes into the cytosol occurs by a pH- and chaperone-dependent translocation mechanism [28], which seems to be common for the binary clostridial actin ADP-ribosylating toxins and was previously investigated for the $\mathrm{C} 2$ and iota toxins in more detail [41,42]. After proteolytic activation, the binding/translocation components of these toxins, C2IIa and Ib, respectively, form heptamers, which bind to their cellular receptors and assemble with the enzyme components C2I and Ia, respectively [41-47]. After receptor-mediated endocytosis of the toxin complexes, the binding/translocation components mediate the translocation of the enzyme components from the lumen of acidified endosomal vesicles into the cytosol $[28,41,42,48,49]$. To this end, the binding/translocation components change their conformation due to the acidic 
conditions, insert into the endosomal membranes and form trans-membrane pores [41,42,48,50-54]. These pores serve as translocation channels for the unfolded enzyme components and are essential prerequisites for their transport across endosomal membranes into the cytosol $[48,53,55]$, which is in analogy with the anthrax toxin $\mathrm{PA}_{63}$ channel [56]. In addition to the pores, cytosolic host cell factors including chaperones and protein folding helper enzymes are involved in membrane translocation of the enzyme components of C2 toxin [57,58], iota toxin [28,59] and CDT [28].

Due to their essential role in toxin uptake, the translocation pores represent attractive molecular drug targets [60] to protect cells from these binary toxins. We and others identified pore blockers for C2 toxin and iota toxin, but also for the related binary anthrax toxin (for review see [61-63]), such as small-molecule positively charged aromatic compounds [64-68] and tailored $\beta$-cyclodextrin derivatives [69-78] and characterized their inhibitory effects on the transmembrane pores formed by these toxins in vitro and in living cells. The tailored seven-fold symmetrical positively charged per-6-S-(3-aminomethyl)benzylthio- $\beta$-cyclodextrin (AMBnT $\beta$-CD, see Figure 1D) efficiently blocks $\mathrm{PA}_{63}$, the translocation pore of anthrax toxin and prevents intoxication with anthrax toxin in vitro, in intact cells and in animal models [69,79]. Recently, we demonstrated that AMBnT $\beta-C D$ is also a potent pore blocker for $\mathrm{C} 2 \mathrm{IIa}$ and $\mathrm{Ib}[74,76]$. AMBnT $\beta-\mathrm{CD}$ protects cultured cells from intoxication with $\mathrm{C} 2$ and iota toxins by inhibiting the channel-mediated membrane translocation of $\mathrm{C} 2 \mathrm{I}$ and $\mathrm{Ib}$ [76]. Since the closely related binding/translocation components of CDT and iota toxin are functionally interchangeable [80] and exploit the same receptor on target cells [24,25], here we investigate whether AMBnT $\beta-C D$ also inhibits translocation of CDTa and protects cells from intoxication with CDT.

\section{Results and Discussion}

\subsection{AMBnT $\beta$-CD Protects Vero Cells from Intoxication with CDT}

Vero cells are the established target cells to probe for CDT cytotoxicity because they efficiently bind and internalize CDT. Vero cells incubated in the presence of CDTa plus CDTb rapidly round up due to the CDTa-catalyzed ADP-ribosylation of G-actin in the cytosol, which results in the depolymerization of F-actin. Therefore, cell rounding indicates the presence of CDTa in the cytosol and represents a highly specific and sensitive endpoint to monitor CDTb-mediated transport of CDTa, because cells treated with CDTa alone do not round up. When Vero cells were pre-treated with $10 \mu \mathrm{M}$ of AMBnT $\beta-C D$, which is a potent pore blocker for the closely related iota toxin [76] and challenged with CDT, a lower percentage of the cells rounded up compared to the cells treated with CDT in the absence of this substance (Figure 1A,B).

The AMBnT $\beta-C D$ concentration was used in this experiment because it was sufficient to significantly delay the intoxication of cultured epithelial cells with $\mathrm{C} 2$ and iota toxins in our earlier study [76]. The solvent DMSO alone had no significant effect on the intoxication of Vero cells with CDT, indicating that the observed inhibitory effect was related to AMBnT $\beta-C D$. In line with this observation, the CDT-induced depolymerization of F-actin was significantly decreased in the presence of AMBnT $\beta-C D$ (Figure 1C). Taken together, these results indicate that less actin was ADP-ribosylated by CDT in the cytosol when cells were pretreated with the inhibitor and suggest that less enzymatic active CDTa reached the cytosol of these cells. However, AMBnT $\beta-C D$ did not 
completely inhibit CDT-induced cell rounding but significantly delayed it, as observed earlier for C2 and iota toxins by using chloroquine derivatives as the pore blockers $[51,67,68]$. The protective effect of AMBnT $\beta-C D$ was more prominent when lower CDT concentrations were used (Figure 2A). These data suggest that a (minor) portion of the internalized CDTa translocates from endosomes into the cytosol over time even in the presence of the pore blocker and this portion is bigger when higher toxin concentrations are applied.

Figure 1. Pre-treatment with AMBnT $\beta-C D$ protects Vero cells from intoxication with Clostridium difficile transferase CDT. (A) Vero cells were grown in 12-well dishes to subconfluency and treated with $10 \mu \mathrm{M}$ final concentrations of AMBnT $\beta-C D$ for $30 \mathrm{~min}$ at $37{ }^{\circ} \mathrm{C}$. Subsequently, $200 \mathrm{ng} / \mathrm{mL}$ CDTb $+100 \mathrm{ng} / \mathrm{mL}$ CDTa were added and cells were further incubated at $37{ }^{\circ} \mathrm{C}$. For control, cells were either left untreated, treated with CDT alone, with AMBnT $\beta-C D$ alone, or with CDT in the presence of solvent. Pictures were taken after different incubation periods, but shown for $3 \mathrm{~h}$ as exemplary measurements; (B) The number of total cells and rounded cells was counted from the pictures and percentage of the round cells was calculated. Values are given as the means \pm S.D. $(n=3)$. Significance was tested for each time point between CDT-treated cells with and without AMBnT $\beta$-CD by using the Student $t$-test $(* * * p<0.0005$; ** $p<0.005$; * $p<0.05$ ); (C) Pretreatment with AMBnT $\beta-C D$ prevents the CDT-induced depolymerization of F-actin in Vero cells. Vero cells grown in a 96 well plate were treated with CDT in the presence and absence of AMBnT $\beta-C D$ as described before. After $2 \mathrm{~h}$, cells were fixed and permeabilized. F-actin was stained with phalloidin-FITC and fluorescence detected at $513 \mathrm{~nm}$ with a TecanReader Infinite M1000 (Tecan Deutschland GmbH, Crailsheim, Germany); (D) The seven-fold symmetrical synthetic molecule AMBnT $\beta-C D$, which was used as CDT toxin blocker in this study.

A
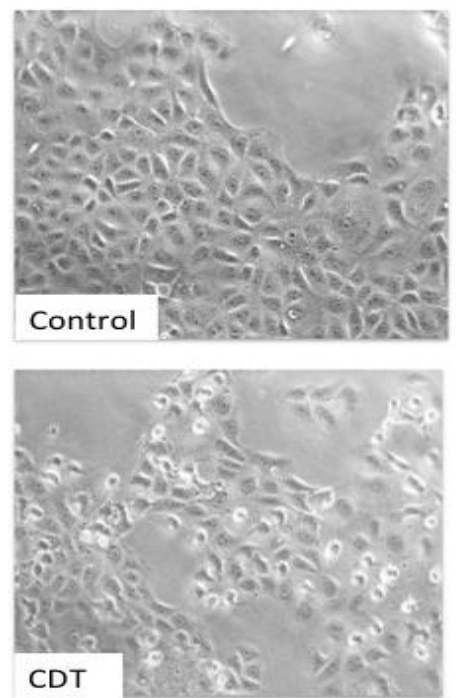
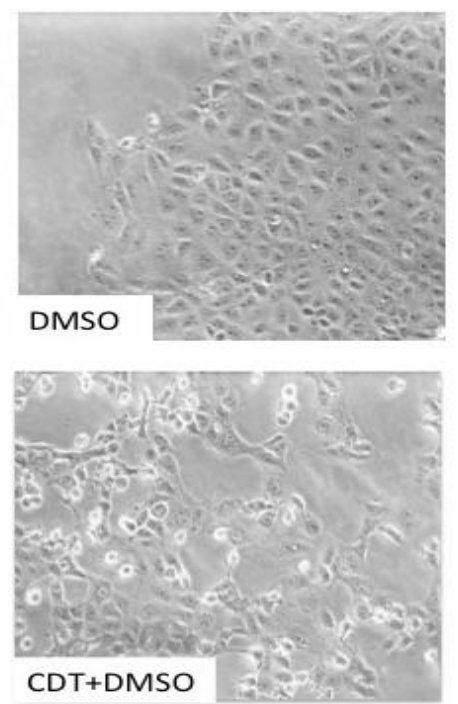
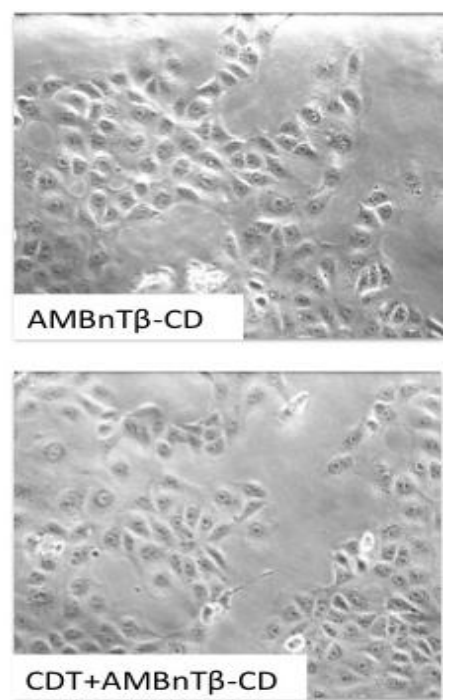
Figure 1. Cont.
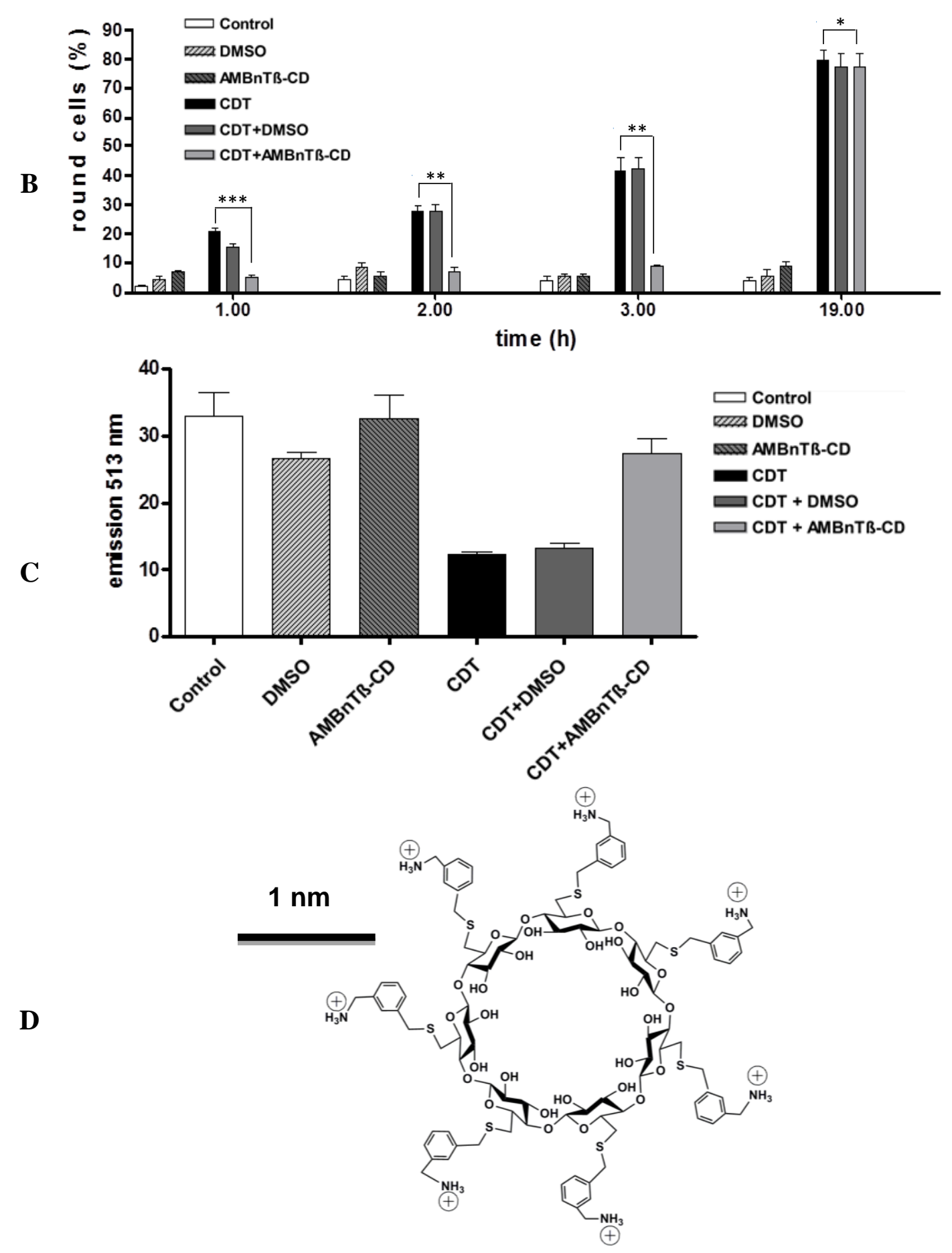

The inhibitory effect of AMBnT $\beta-C D$ on the intoxication of Vero cells with CDT was concentration-dependent as shown in Figure $2 \mathrm{~B}$. While 1 and $5 \mu \mathrm{M}$ final concentrations of this compound had only small inhibitory effects in the very early phase of intoxication, the 10 and $20 \mu \mathrm{M}$ concentrations significantly delayed cell rounding to the extent of $24 \mathrm{~h}$ after CDT application. Under the conditions used in this experiment, $20 \mu \mathrm{M}$ of $\mathrm{AMBnT} \beta-\mathrm{CD}$ completely inhibited the intoxication for $4 \mathrm{~h}$. Of note, we have demonstrated earlier that treatment of Vero cells with AMBnT $\beta$-CD alone up to $20 \mu \mathrm{M}$ final concentration in the medium for $72 \mathrm{~h}$ has no effect on the morphology of Vero cells [76]. 
Figure 2. AMBnT $\beta-C D$ delays the intoxication of Vero cells with CDT in a concentration-dependent manner. (A) Effects of AMBnT $\beta-C D(10 \mu \mathrm{M})$ on intoxication of Vero cells after application of different concentrations of CDT. Vero cells were treated with $10 \mu \mathrm{M}$ AMBnT $\beta-C D$ for $30 \mathrm{~min}$ at $37{ }^{\circ} \mathrm{C}$. Subsequently, CDT $(200 \mathrm{ng} / \mathrm{mL} \mathrm{CDTb}+$ $100 \mathrm{ng} / \mathrm{mL}$ CDTa, or $100 \mathrm{ng} / \mathrm{mL} \mathrm{CDTb}+50 \mathrm{ng} / \mathrm{mL}$ CDTa) was added and cells were further incubated at $37{ }^{\circ} \mathrm{C}$. For control, cells were either left untreated, or treated with the indicated concentrations of CDT alone or with AMBnT $\beta-C D$ alone. Pictures were taken after the indicated incubation times (shown for $4 \mathrm{~h}$ ); (B) Percentages of round cells calculated from the pictures. Values are given as the means \pm S.D. $(n=3)$ and significance was tested for each time point between the CDT-treated samples with or without AMBnT $\beta$-CD by using the Student $t$-test $(* * * p<0.0005$; ** $p<0.005$; $* p<0.05$; $\mathrm{ns}=$ not significant); (C) Subconfluent Vero cells were pre-treated for $30 \mathrm{~min}$ at $37{ }^{\circ} \mathrm{C}$ with 1, 5, 10 and $20 \mu \mathrm{M}$ of AMBnT $\beta$-CD and CDT (50 ng/mL CDTb $+25 \mathrm{ng} / \mathrm{mL} \mathrm{CDTa)}$ was added to the medium. For control, cells were left untreated, or treated with CDT alone or with AMBnT $\beta-C D(20 \mu \mathrm{M})$ alone. After the indicated incubation times pictures were taken, as shown for $5 \mathrm{~h}$; (D) the percentages of round cells were calculated from the pictures. Values are given as the means \pm S.D. $(n=3)$ and significance was tested for each time point between CDT-treated samples with or without AMBnT $\beta-C D$ by using the Student $t$-test $(* * * p<0.0005 ; * * p<0.005 ; * p<0.05$; ns = not significant).

A
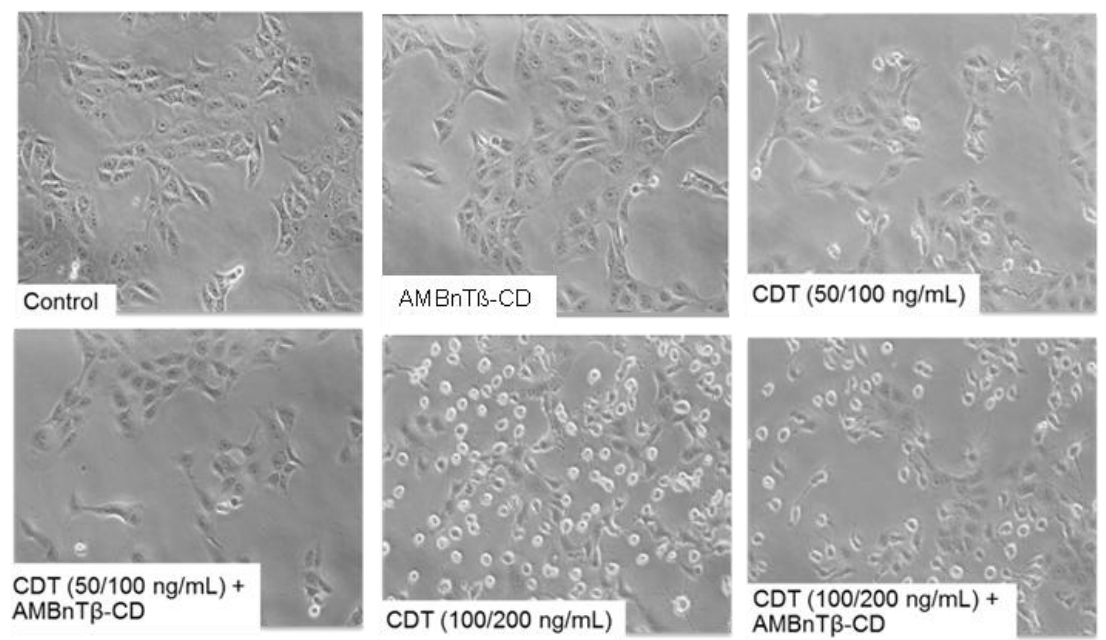

B $\square$ Control

AMBnTB-CD

- CDT $(50 / 100 \mathrm{ng} / \mathrm{mL})$

$\square$ CDT $(50 / 100 \mathrm{ng} / \mathrm{mL})+A M B n T ß-C D$

27. CDT $(100 / 200 \mathrm{ng} / \mathrm{mL})$

ZZ CDT $(100 / 200 \mathrm{ng} / \mathrm{mL})+A M B n T B-C D$
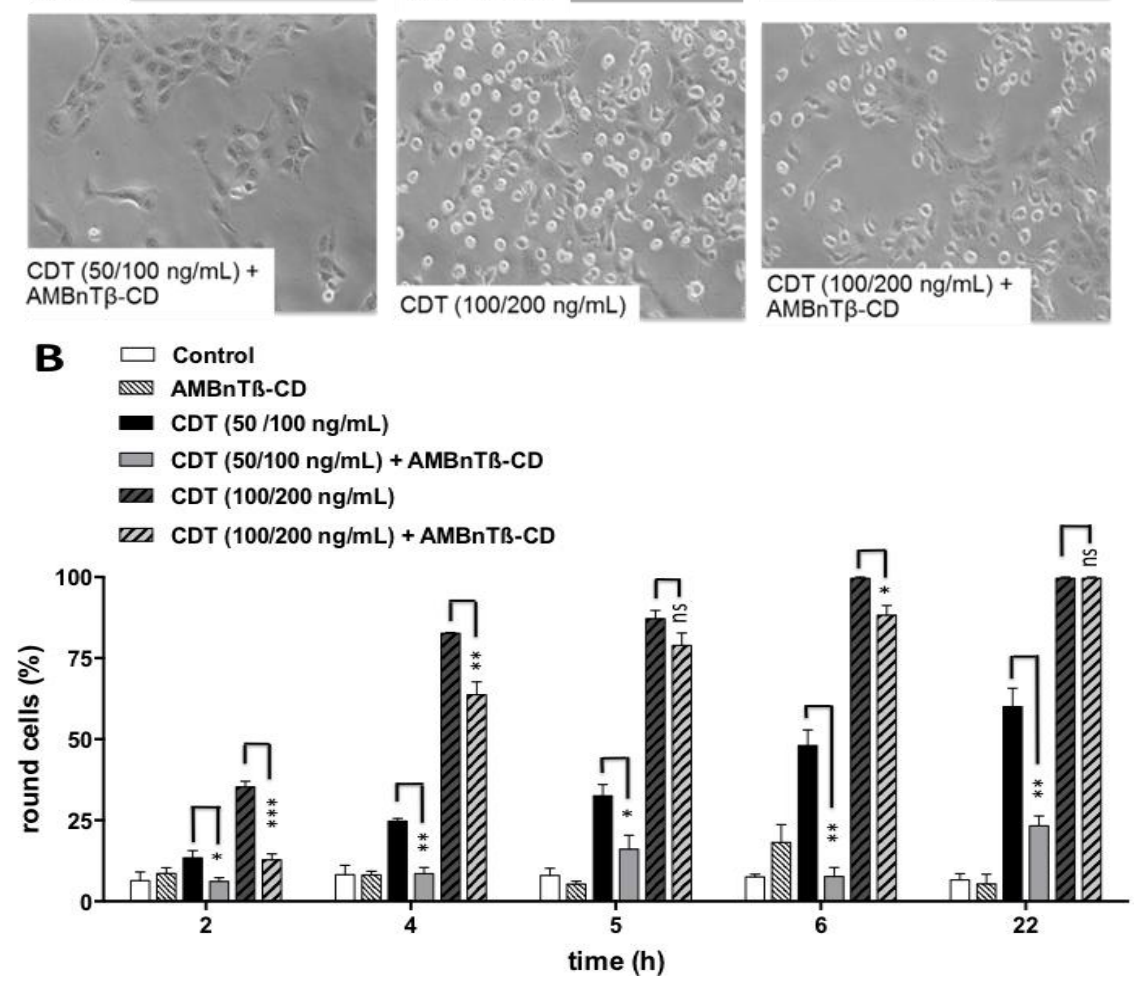
Figure 2. Cont.

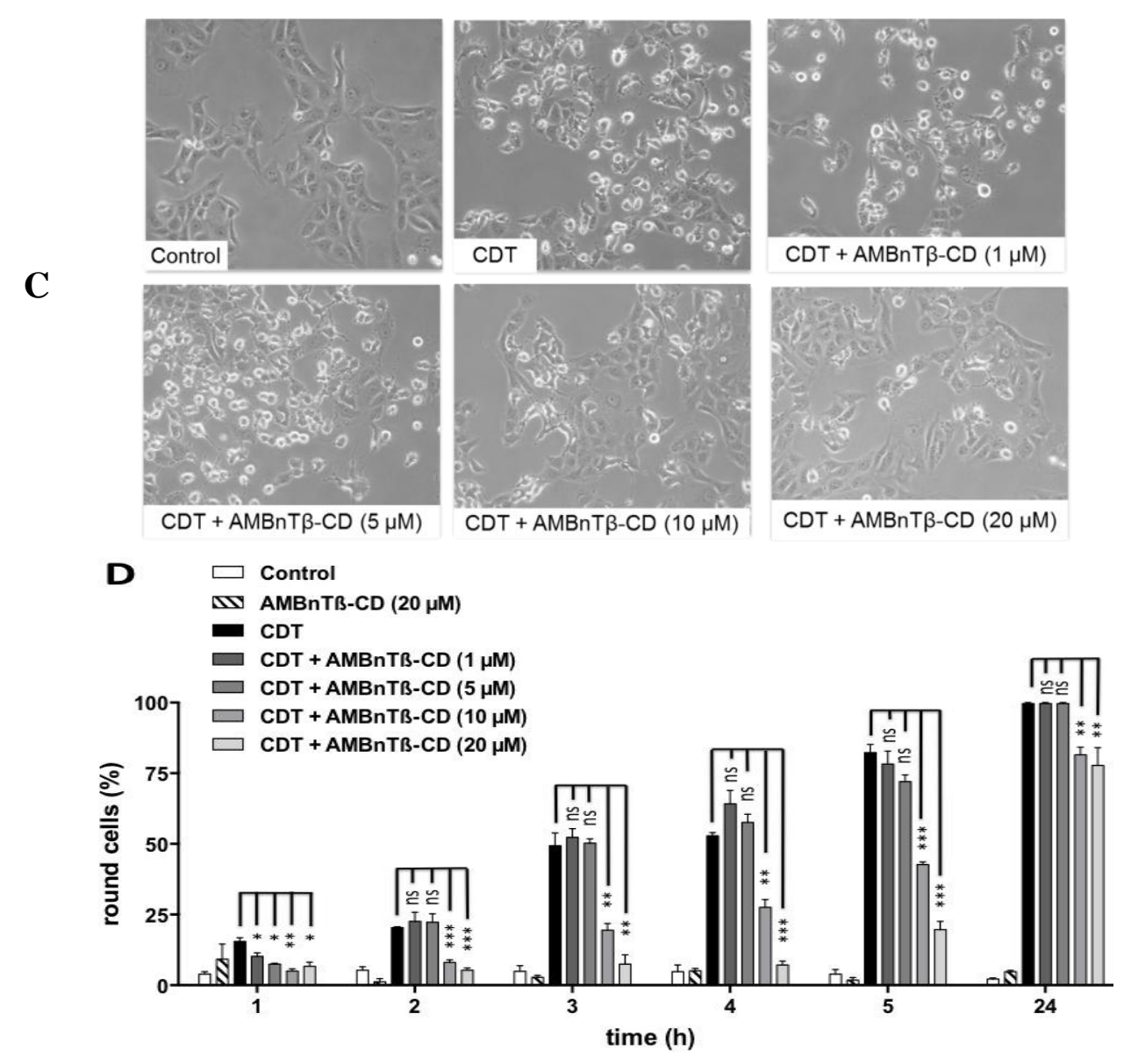

\subsection{The Inhibitory Effect Depends on the Time Point of AMBnTB-CD Application}

AMBnT $\beta-C D$ inhibited the intoxication of Vero cells with CDT not only when applied prior to CDT, but also when added at the same time point into the medium or even 10 min after CDT (Figure 3).

AMBnT $\beta-C D$ had no significant inhibitory effect towards CDT when applied 30 min after the toxin, comparable to what we observed earlier for $\mathrm{C} 2$ toxin [76]. This is plausible because we previously determined that AMBnT $\beta-C D$ acts by blocking the translocation pores of the toxins in endosomal vesicles thereby preventing translocation of their enzyme components into the cytosol. Within $30 \mathrm{~min}$, most of the internalized CDTa would be translocated into the cytosol and therefore would not be targeted by AMBnT $\beta$-CD. In this context, we demonstrated earlier that AMBnT $\beta-C D$ has no effect on the C2I-catalyzed ADP-ribosylation of actin [76] and, in line with this finding, $10 \mu \mathrm{M}$ of AMBnT $\beta-C D$ had no inhibitory effect on the ADP-ribosylation of actin by CDTa in vitro (Figure 4A).

$A M B n T \beta-C D$ did not interfere with binding of $\mathrm{CDTb}$ to its receptor (Figure 4B). When cells were pretreated with AMBnT $\beta$-CD and subsequently incubated at $4{ }^{\circ} \mathrm{C}$ with $\mathrm{CDTb}$ to enable its binding to the receptors on the cell surface, there were no obvious differences in the amounts of cell-bound CDTb in a Western blot analysis compared to the cells treated with CDTb in the absence of AMBnT $\beta-C D$. 
Figure 3. The time point of $A M B n T \beta-C D$ application determines its protective effect against CDT. (A) AMBnT $\beta$-CD $(10 \mu \mathrm{M})$ was added to Vero cells either 10 min before, or at the same time point, or 10 or $30 \mathrm{~min}$ after CDT $(50 \mathrm{ng} / \mathrm{mL} \mathrm{CDTb}+25 \mathrm{ng} / \mathrm{mL} \mathrm{CDTa})$. For control, cells were left untreated or treated with CDT alone or with AMBnT $\beta-C D$ $(10 \mu \mathrm{M})$ alone. The cells were incubated at $37{ }^{\circ} \mathrm{C}$ and pictures were taken after the indicated time points (shown for $5 \mathrm{~h}$ ); (B) The percentage of round cells was determined from the pictures. Values are given as the means \pm S.D. $(n=3)$ and significance was tested for each sample treated with CDT and AMBnT $\beta-C D$ against cells treated with CDT alone by using the Student $t$-test $(* * * p<0.0005 ; * * p<0.005 ; * p<0.05$; ns $=$ not significant).

A
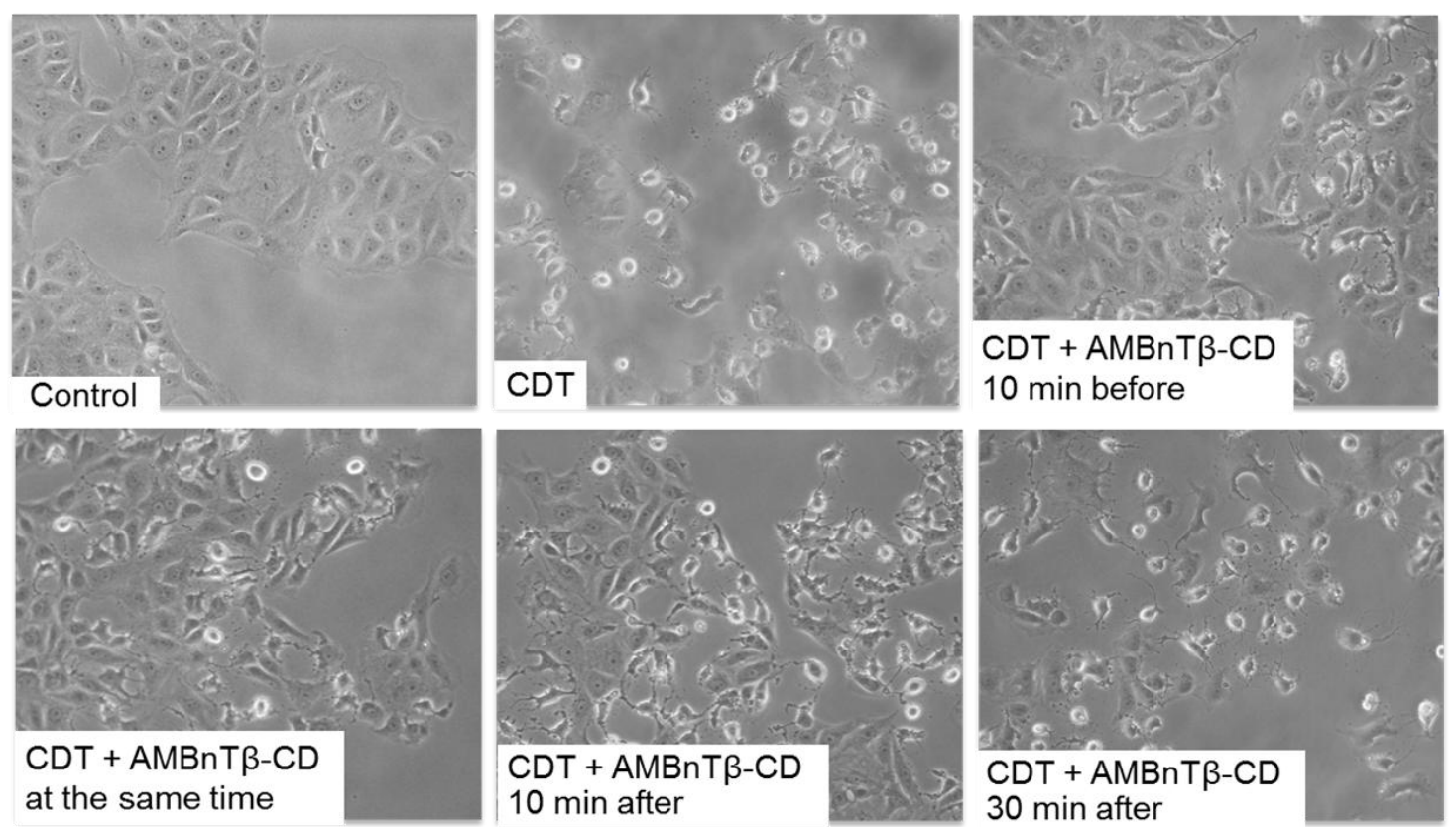

B

$\square$ Control

30 min after

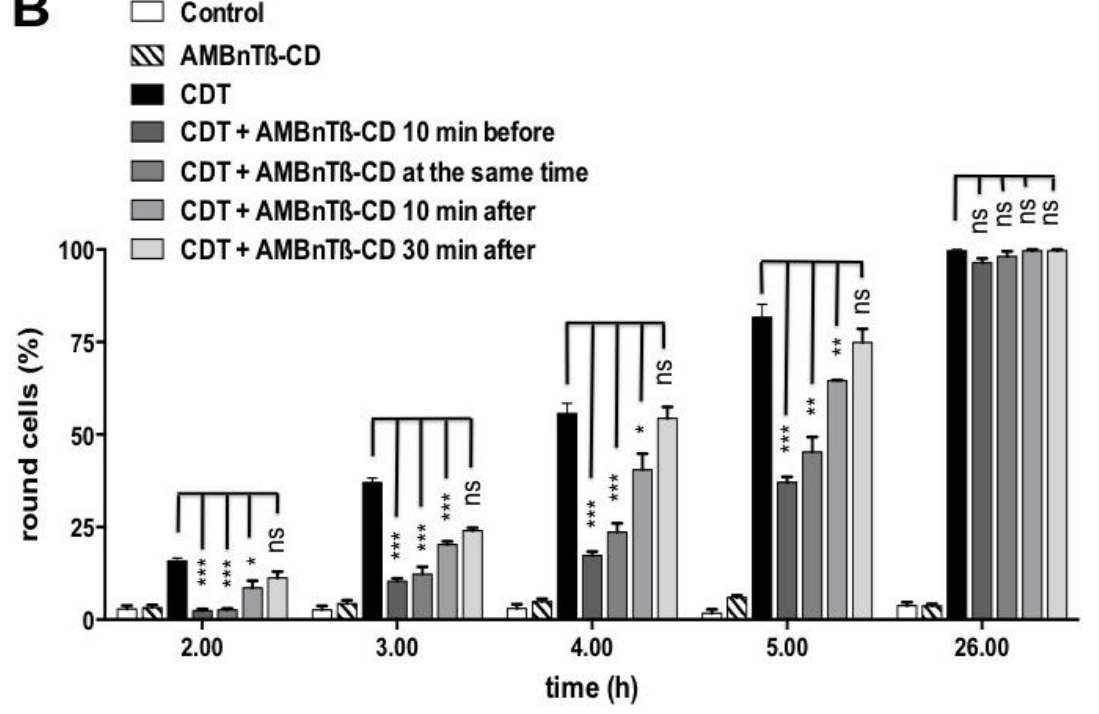


Figure 4. AMBnT $\beta-C D$ does not inhibit the enzyme activity of CDTa or the binding of CDT to cells. (A) Effect of AMBnT $\beta-C D$ on the CDTa-catalyzed ADP-ribosylation of actin in vitro. Vero cell lysate $\left(10 \mu \mathrm{g}\right.$ of protein) was preincubated for $10 \mathrm{~min}$ at $37{ }^{\circ} \mathrm{C}$ with AMBnT $\beta$-CD $(10 \mu \mathrm{M})$ and subsequently $500 \mathrm{ng}$ of CDTa and $10 \mu \mathrm{M}$ of biotin-NAD ${ }^{+}$were added. For control, lysate proteins were incubated without CDTa or without AMBnT $\beta$-CD. After 30 min incubation at $37^{\circ} \mathrm{C}$, the proteins were separated by SDS-PAGE, blotted onto nitrocellulose and the ADP-ribosylated (i.e., biotin-labelled) actin was detected by Western blotting with streptavidin-peroxidase. Comparable amounts of blotted protein were confirmed by Ponceau S-staining (not shown). The two lanes are duplicates from the same experiment; (B) Effect of AMBnT $\beta-C D$ on binding of CDTb to Vero cells. Cells were incubated for $10 \mathrm{~min}$ at $37{ }^{\circ} \mathrm{C}$ with or without AMBnT $\beta-\mathrm{CD}(10 \mu \mathrm{M})$ and for additional $30 \mathrm{~min}$ at $4{ }^{\circ} \mathrm{C}$ with $\mathrm{CDTb}(300 \mathrm{ng} / \mathrm{mL})$ to enable its binding to the cell receptors. After removal of the medium and extensive washing, cells were lysed and equal amounts of lysate proteins were separated by SDS-PAGE and blotted onto a nitrocellulose membrane. The cell-bound CDTb was detected by Western blotting with a specific antibody against Ib, which cross reacts with CDTb. Comparable amounts of blotted protein were confirmed by Ponceau S-staining (not shown). The two lanes are duplicates from the same experiment.

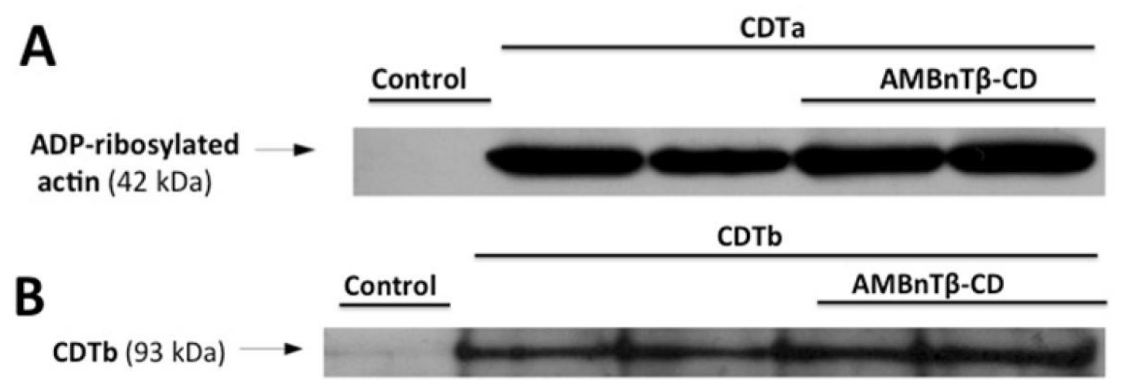

Having confirmed that AMBnT $\beta-C D$ did not interfere with binding of CDT to the cells and with CDTa-catalyzed ADP-ribosylation of actin, we finally tested the effect of AMBnT $\beta$-CD on $\mathrm{pH}$-mediated membrane translocation of CDTa. To this end, we performed an established assay where the conditions in the lumen of acidified endosomal vesicles are mimicked on the surface of cultured cells, as originally described for diphtheria toxin [81]. After binding of CDT to Vero cells at $4{ }^{\circ} \mathrm{C}$, cells were exposed to an acidic pulse to trigger insertion of CDTb pores into the cytoplasmic membrane and translocation of CDTa through these pores into the cytosol. Noteworthy, the "normal" uptake of CDT via acidified endosomes was blocked by incubating the cells with bafilomycin A1. Since only translocated CDTa modifies actin in the cytosol and thereby induces cell rounding, the percentage of round cells allows monitoring toxin translocation under these conditions [28]. To investigate whether AMBnT $\beta-C D$ interferes with the CDT translocation, cells, which have bound CDT on their surface, were incubated with this compound $10 \mathrm{~min}$ prior to and during the $\mathrm{pH}$ pulse. The results shown in Figure 5 indicate that less cells rounded up when AMBnT $\beta-C D$ was present, implicating that translocation of CDTa was inhibited. 
Figure 5. Effect of AMBnT $\beta-\mathrm{CD}$ on the $\mathrm{pH}$-induced translocation of CDT across the cytoplasmic membrane of Vero cells. Cells were pre-treated for $30 \mathrm{~min}$ at $37{ }^{\circ} \mathrm{C}$ with $100 \mathrm{nM}$ bafilomycin (Baf) A1 and subsequently incubated for $30 \mathrm{~min}$ on ice with CDT $(100 \mathrm{ng} / \mathrm{mL} \mathrm{CDTa}+200 \mathrm{ng} / \mathrm{mL}$ CDTb$)$, or for control without CDT. To one portion of CDT-treated cells, $20 \mu \mathrm{M}$ of AMBnT $\beta-C D$ (or DMSO as solvent control to the other portion of CDT-treated cells) was added after $20 \mathrm{~min}$ on ice. All cells were incubated at $37{ }^{\circ} \mathrm{C}$ for $15 \mathrm{~min}$ in acidic medium $(\mathrm{pH} \mathrm{4.5)}$ and for further $2 \mathrm{~h}$ in neutral medium and after $2 \mathrm{~h}$ pictures were taken to determine the percentage of round cells. Values are the means \pm S.D. $(n=3)$. Significance between CDT-treated cells and CDT + AMBnT $\beta-C D$-treated cells was tested by using the Student $t$-test $(* * p<0.005)$.
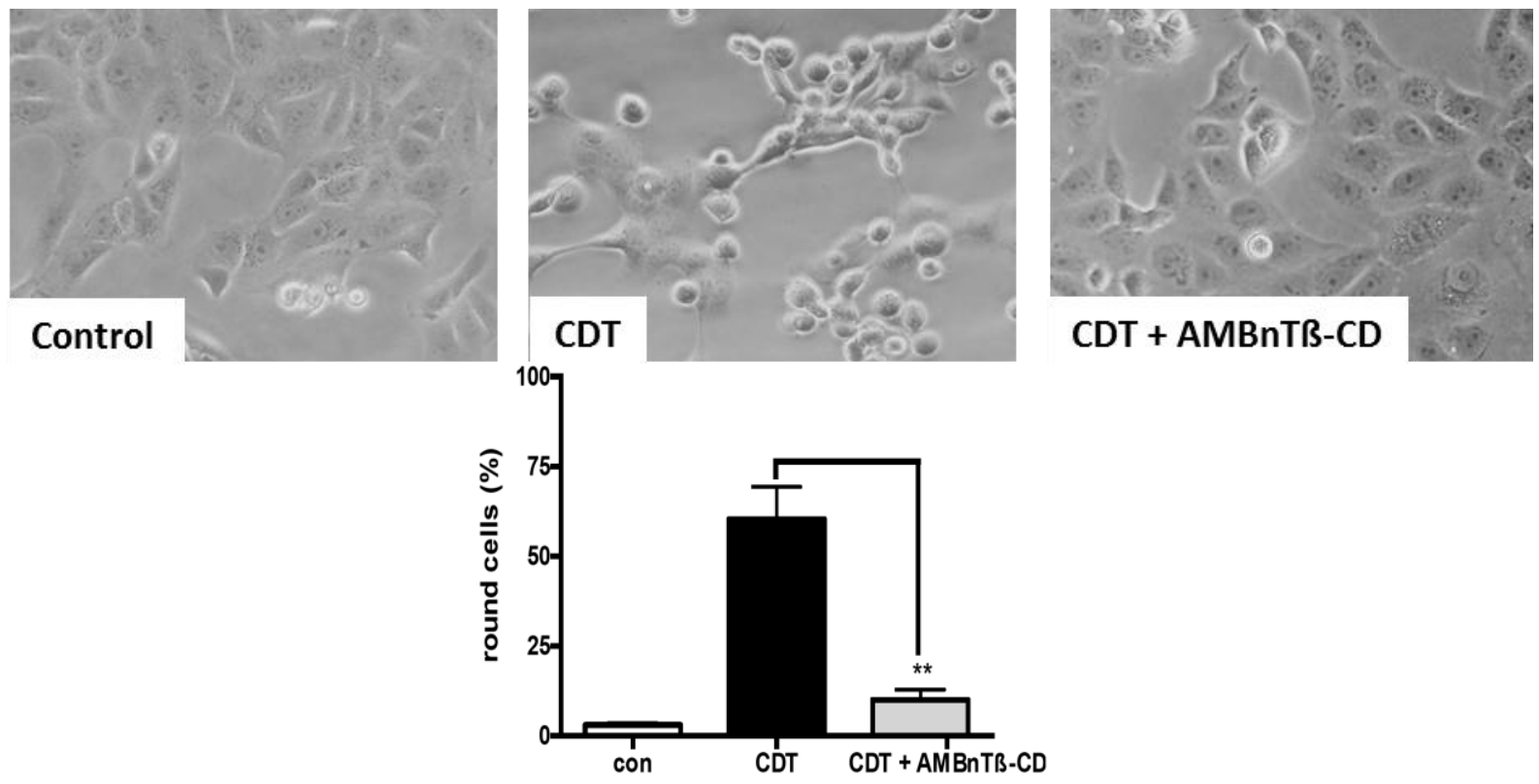

Comparable inhibitory effects of $\mathrm{AMBnT} \beta-\mathrm{CD}$ on the $\mathrm{pH}$-triggered membrane translocation were earlier obtained for the related binary $\mathrm{C} 2$ and iota toxins [76], confirming that this inhibitor targets the hepatmeric transmembrane pores of binary actin ADP-ribosylating toxins and prevents translocation of their enzyme components into the cytosol of mammalian target cells.

\section{Experimental Section}

\subsection{Materials and Reagents}

Cell culture medium MEM and fetal calf serum were purchased from Invitrogen (Karlsruhe, Germany) and cell culture materials from TPP (Trasadingen, Switzerland). Complete ${ }^{\circledR}$ protease inhibitor was from Roche (Mannheim, Germany), the protein molecular weight marker Page Ruler prestained Protein ladder ${ }^{\circledR}$ from Fermentas (St. Leon-Rot, Germany), biotin-labelled NAD ${ }^{+}$from $\mathrm{R}$ \& D Systems GmbH (Wiesbaden-Nordenstadt, Germany), bafilomycin A1 from Calbiochem (Bad Soden, Germany). AMBnT $\beta-C D$ was custom synthesized at LycloLab (Budapest, Hungary) as described in detail previously (compound 14b, [70]). CDTa and CDTb (from C. difficile strain 196) were expressed as recombinant His-tagged proteins in the B. megaterium expression system and purified as described earlier [24]. 


\subsection{Cell Culture and Intoxication Assays}

African green monkey kidney (Vero) cells were cultivated at $37{ }^{\circ} \mathrm{C}$ and $5 \% \mathrm{CO}_{2}$ in $\mathrm{MEM}$ containing $10 \%$ heat-inactivated fetal calf serum, $1.5 \mathrm{~g} / \mathrm{L}$ sodium bicarbonate, $1 \mathrm{mM}$ sodium-pyruvate, $2 \mathrm{mM}$ L-glutamine, $0.1 \mathrm{mM}$ non-essential amino acids and $10 \mathrm{mg} / \mathrm{mL}$ Penicillin/Streptomycin. Vero cells were trypsinized and reseeded twice a week for at most 15-20 times. For cytotoxicity experiments, cells grown in culture dishes in serum-free medium were incubated at $37{ }^{\circ} \mathrm{C}$ with CDT and after the indicated incubation periods visualized by using a Zeiss Axiovert 40CFl microscope (Oberkochen, Germany) with a Jenoptik progress C10 CCD camera (Carl Zeiss GmbH, Jena, Germany). The CDT-induced cell rounding as specific indication of the intoxication process and inhibitory effects of AMBnT $\beta-C D$ were analysed by incubating cells with CDT in the presence and absence of this substance. The percentage of round cells was determined from the pictures. The $\mathrm{pH}$-induced translocation of cell-bound CDT across the cytoplasmic membrane of Vero cells was performed as described earlier [28].

\subsection{Quantification of F-Actin Content in Cells}

Vero cells grown in a 96-well plate were pre-treated for $30 \mathrm{~min}$ at $37{ }^{\circ} \mathrm{C}$ with AMBnT $\beta$-CD or left untreated for control. Then, cells were incubated for further $2 \mathrm{~h}$ with CDT. As an additional control, cells were left untreated. Subsequently, the medium was removed and cells were fixed by $20 \mathrm{~min}$ incubation with paraformaldehyde (4\% in PBS) and permeabilized with Triton-X100 (0.4\% in PBS). Non-specific binding sites were blocked by incubating the cells for $45 \mathrm{~min}$ with $5 \%$ non-fat dry milk in PBS containing $0.1 \%$ Tween-20 (PBS-T) and F-actin was stained by 45 min incubation at $37{ }^{\circ} \mathrm{C}$ with phalloidin-FITC. Cells were washed and the fluorescence measured at $513 \mathrm{~nm}$ emission with a TecanReader Infinite M1000 (Tecan Germany, Crailsheim, Germany).

\subsection{SDS-PAGE and Western Blotting}

For the Western blot analysis of cell-bound CDTb, cells were incubated for 30 min at $4{ }^{\circ} \mathrm{C}$ with $\mathrm{CDTb}$ in the presence (10 min pre-treatment) or absence of AMBnT $\beta-C D$, washed and lysed. Equal amounts of lysate protein were subjected to SDS-PAGE according to the method of Laemmli [82] and blotted onto a nitrocellulose membrane (Whatman, Dassel, Germany). The membrane was blocked for 30 min with 5\% non-fat dry milk in PBS-T and probed with a specific antibody against iota $\mathrm{b}$ (a kind gift from Bradley G. Stiles, Integrated Toxicology, Bacteriology Divisions, U.S. Army Medical Research Institute of Infectious Diseases, Fort Detrick, MD, USA), which cross-reacts with the closely related CDTb. The membrane was washed with PBS-T, incubated with anti-rabbit antibody coupled to horseradish peroxidase (Santa-Cruz, Heidelberg, Germany), washed again, and CDTb was detected with the enhanced chemiluminescence (ECL) system from Millipore (Schwalbach, Germany) according to the manufacturer's instructions.

\subsection{ADP-Ribosylation of Actin by CDTa in a Cell-Free System}

Vero cell lysate $\left(10 \mu \mathrm{g}\right.$ of protein) was pre-incubated for $10 \mathrm{~min}$ at $37{ }^{\circ} \mathrm{C}$ together with the inhibitor AMBnT $\beta-C D$ or left untreated for control. Subsequently, $500 \mathrm{ng} / \mathrm{mL}$ of CDTa and $10 \mu \mathrm{M}$ 
biotin-NAD ${ }^{+}$were added and the samples incubated for 30 min at $37{ }^{\circ} \mathrm{C}$. Then, the proteins were subjected to SDS-PAGE, blotted onto a nitrocellulose membrane and the biotin-labelled, i.e., ADP-ribosylated, actin was detected by Western blotting with streptavidin-peroxidase and the ECL system. Intensity of biotin-actin was measured by densitometry using the Adobe Photoshop software (version 7.0, Adobe Systems GmbH, Munich, Germany, 2002).

\subsection{Reproducibility of the Experiments and Statistics}

All experiments were performed independently at least two times and results from representative experiments are shown in the figures. For quantification, the values $(n=3)$ were calculated as the means \pm standard deviation (S.D.) with the Prism4 Software (GraphPad Software, Inc., La Jolla, CA, USA). Significance was tested with the Student $t$-test.

\section{Conclusions}

We have performed a series of experiments to demonstrate that the symmetrical positively charged $\beta$-cyclodextrin derivative, per-6-S-(3-aminomethyl)benzylthio- $\beta$-cyclodextrin (AMBnT $\beta$-CD), efficiently protects cultured epithelial cells from intoxication with the binary toxin CDT of $C$. difficile. The more detailed investigation of the underlying mechanism strongly suggests that this compound inhibited the $\mathrm{pH}$-dependent translocation of the enzyme component CDTa across cell membranes, which is mediated by trans-membrane pores formed by the separate binding/translocation component $\mathrm{CDTb}$. This finding is in agreement with our recent data showing that AMBnT $\beta-C D$ blocks the translocation pores of the closely related binary C2 and iota toxins [74,76], thereby protecting cells from intoxication. This substance was originally generated as a tailored blocker for the translocation pore of the binary toxins of Bacillus anthracis, protective antigen [69], which shares the overall structure and mode of action with the translocation pores of the clostridial binary toxins [22,62]. Indirectly, our findings suggest that the CDTb pores, which have not been characterized as trans-membrane channels in vitro so far, might play an essential role for the translocation of CDTa across membranes during uptake of CDT into the targeted mammalian cells.

However, the findings might also have an important medical implication since the observed inhibitory effects of AMBnT $\beta$-CD suggest that this compound could serve as the broad-spectrum inhibitor against binary bacterial toxins that form oligomeric translocation channels to deliver their enzymatic active components into the host cell cytosol. Moreover, since the CDT-production contributes to the hypervirulence of $C$. difficile, $\mathrm{AMBnT} \beta-\mathrm{CD}$ might be an attractive lead compound to develop novel pharmacological strategies against these hypervirulent, CDT-producing strains.

\section{Acknowledgments}

We thank Ulrike Binder for excellent technical assistance and Tanja Weil (Institute of Organic Chemistry III, University of Ulm) for providing the Tecan instrument. The work was financially supported by the Deutsche Forschungsgemeinschaft DFG (grant BA 2087/2-2). 


\section{Author Contributions}

Conceived and designed the experiments: Maurice Roeder, Holger Barth; Performed the experiments: Maurice Roeder, Holger Barth; Analyzed the data: Maurice Roeder, Holger Barth; Wrote the paper: Maurice Roeder, Holger Barth; Contributed essential materials, reagents, tools: Ekaterina M. Nestorovich, Vladimir A. Karginov, Carsten Schwan, Klaus Aktories.

\section{Conflicts of Interest}

The authors declare no conflict of interest.

\section{References}

1. Heinlen, L.; Ballard, J.D. Clostridium difficile infection. Am. J. Med. Sci. 2010, 340, 247-252.

2. Just, I.; Selzer, J.; Wilm, M.; von Eichel-Streiber, C.; Mann, M.; Aktories, K. Glucosylation of Rho proteins by Clostridium difficile toxin B. Nature 1995, 375, 500-503

3. Just, I.; Wilm, M.; Selzer, J.; Rex, G.; von Eichel-Streiber, C.; Mann, M.; Aktories, K. The enterotoxin from Clostridium difficile (ToxA) monoglucosylates the Rho proteins. J. Biol. Chem. 1995, 270, 13932-13936.

4. Jank, T.; Aktories, K. Structure and mode of action of clostridial glucosylating toxins: The ABCD model. Trends Microbiol. 2008, 16, 222-229.

5. Popoff, M.R.; Rubin, E.J.; Gill, D.M.; Boquet, P. Actin-specific ADP-ribosyltransferase produced by a Clostridium difficile strain. Infect. Immun. 1988, 56, 2299-2306.

6. Perelle, S.; Gibert, M.; Bourlioux, P.; Corthier, G.; Popoff, M.R. Production of a complete binary toxin (actin-specific ADP-ribosyltransferase) by Clostridium difficile CD196. Infect. Immun. 1997, 65, 1402-1407.

7. Gerding, D.N.; Johnson, S.; Rupnik, M.; Aktories, K. Clostridium difficile binary toxin CDT: Mechanism, epidemiology, and potential clinical importance. Gut Microbes 2014, 5, 1-13.

8. Stubbs, S.; Rupnik, M.; Gibert, M.; Brazier, J.; Duerden, B.; Popoff, M.R. Production of actin-specific ADP-ribosyltransferase (binary toxin) by strains of Clostridium difficile. FEMS Microbiol. Lett. 2000, 186, 307-312.

9. Geric, B.; Rupnik, M.; Gerding, D.N.; Grabnar, M.; Johnson, S. Distribution of Clostridium difficile variant toxinotypes and strains with binary toxin genes among clinical isolates in an American hospital. J. Med. Microbiol. 2004, 53, 887-894.

10. Goncalves, C.; Decre, D.; Barbut, F.; Burghoffer, B.; Petit, J.C. Prevalence and characterization of a binary toxin (actin-specific ADP-ribosyltransferase) from Clostridium difficile. J. Clin. Microbiol. 2004, 42, 1933-1939.

11. McDonald, L.C.; Killgore, G.E.; Thompson, A.; Owens, R.C., Jr.; Kazakova, S.V.; Sambol, S.P.; Johnson, S.; Gerding, D.N. An epidemic, toxin gene-variant strain of Clostridium difficile. N. Engl. J. Med. 2005, 353, 2433-2441.

12. Martin, H.; Willey, B.; Low, D.E.; Staempfli, H.R.; McGeer, A.; Boerlin, P.; Mulvey, M.; Weese, J.S. Characterization of Clostridium difficile strains isolated from patients in Ontario, Canada, from 2004 to 2006. J. Clin. Microbiol. 2008, 46, 2999-3004. 
13. Kuehne, S.A.; Collery, M.M.; Kelly, M.L.; Cartman, S.T.; Cockayne, A.; Minton, N.P. Importance of toxin A, toxin B, and CDT in virulence of an epidemic Clostridium difficile strain. J. Infect. Dis. 2014, 209, 83-86.

14. Aktories, K.; Bärmann, M.; Ohishi, I.; Tsuyama, S.; Jakobs, K.H.; Habermann, E. Botulinum C2 toxin ADP-ribosylates actin. Nature 1986, 322, 390-392.

15. Ohishi, I.; Iwasaki, M.; Sakaguchi, G. Purification and characterization of two components of botulinum C2 toxin. Infect. Immun. 1980, 30, 668-673.

16. Ohishi, I.; Tsuyama, S. ADP-ribosylation of nonmuscle actin with component I of C2 toxin. Biochem. Biophys. Res. Commun. 1986, 136, 802-806.

17. Songer, J.G. Clostridial enteric diseases of domestic animals. Clin. Microbiol. Rev. 1996, 9, 216-234.

18. Stiles, B.G.; Wilkins, T.D. Purification and characterization of Clostridium perfringens iota toxin: Dependence on two nonlinked proteins for biological activity. Infect. Immun. 1986, 54, 683-688.

19. Stiles, B.G.; Wilkins, T.D. Clostridium perfringens iota toxin: Synergism between two proteins. Toxicon 1986, 24, 767-773.

20. Sakurai, J.; Nagahama, M.; Oda, M.; Tsuge, H.; Kobayashi, K. Clostridium perfringens iota-toxin: Structure and function. Toxins 2009, 1, 208-228.

21. Popoff, M.R.; Boquet, P. Clostridium spiroforme toxin is a binary toxin which ADP-ribosylates cellular actin. Biochem. Biophys. Res. Commun. 1988, 152, 1361-1368.

22. Barth, H.; Aktories, K.; Popoff, M.R.; Stiles, B.G. Binary bacterial toxins: biochemistry, biology, and applications of common Clostridium and Bacillus proteins Microbiol. Mol. Biol. Rev. 2004, 8, 373-402.

23. Barth, H.; Aktories, K. New insights into the mode of action of the actin ADP-ribosylating virulence factors Salmonella enterica SpvB and Clostridium botulinum C2 toxin. Eur. J. Cell. Biol. 2011, 90, 944-950.

24. Papatheodorou, P.; Carette, J.E.; Bell, G.W.; Schwan, C.; Guttenberg, G.; Brummelkamp, T.R.; Aktories, K. Lipolysis-stimulated lipoprotein receptor (LSR) is the host receptor for the binary toxin Clostridium difficile transferase (CDT). Proc. Natl. Acad. Sci. USA. 2011, 108, 16422-16427.

25. Papatheodorou, P.; Wilczek, C.; Nölke, T.; Guttenberg, G.; Hornuss, D.; Schwan, C.; Aktories, K. Identification of the cellular receptor of Clostridium spiroforme toxin. Infect. Immun. 2012, 80, 1418-1423.

26. Papatheodorou, P.; Hornuss, D.; Nölke, T.; Hemmasi, S.; Castonguay, J.; Picchianti, M.; Aktories, K. Clostridium difficile binary toxin CDT induces clustering of the lipolysis-stimulated lipoprotein receptor into lipid rafts. MBio 2013, 4, e00244-13. doi:10.1128/mBio.00244-13.

27. Wigelsworth, D.J.; Ruthel, G.; Schnell, L.; Herrlich, P.; Blonder, J.; Veenstra, T.D.; Carman, R.J.; Wilkins, T.D.; van Nhieu, G.T.; Pauillac, S.; et al. CD44 promotes intoxication by the clostridial iota-family toxins. PLoS One 2012, 7, e51356.

28. Kaiser, E.; Kroll, C.; Ernst, K.; Schwan, C.; Popoff, M.R.; Fischer, G.; Buchner, J.; Aktories, K.; Barth, H. Membrane translocation of binary actin-ADP-ribosylating toxins from Clostridium difficile and Clostridium perfringens is facilitated by cyclophilin A and Hsp90. Infect. Immun. 2011, 79, 3913-3921. 
29. Gülke, I.; Pfeifer, G.; Liese, J.; Fritz, M.; Hofmann, F.; Aktories, K.; Barth, H. Characterization of the enzymatic component of the ADP-ribosyltransferase toxin CDTa from Clostridium difficile. Infect. Immun. 2001, 69, 6004-6011.

30. Aktories, K.; Wegner, A. ADP-ribosylation of actin by clostridial toxins. J. Cell Biol. 1989, 109, 1385-1387.

31. Vandekerckhove, J.; Schering, B.; Bärmann, M.; Aktories, K. Clostridium perfringens iota toxin ADP-ribosylates skeletal muscle actin in Arg-177. FEBS Lett. 1987, 225, 48-52.

32. Vandekerckhove, J.; Schering, B.; Bärmann, M.; Aktories, K. Botulinum C2 toxin ADP-ribosylates cytoplasmic $\beta / \gamma$-actin in arginine 177. J. Biol. Chem. 1988, 263, 696-700.

33. Schering, B.; Bärmann, M.; Chhatwal, G.S.; Geipel, U.; Aktories, K. ADP-ribosylation of skeletal muscle and non-muscle actin by Clostridium perfringens iota toxin. Eur. J. Biochem. 1988, 171, 225-229.

34. Weigt, C.; Just, I.; Wegner, A.; Aktories, K. Nonmuscle actin ADP-ribosylated by botulinum C2 toxin caps actin filaments. FEBS Lett. 1989, 246, 181-184.

35. Wiegers, W.; Just, I.; Müller, H.; Hellwig, A.; Traub, P.; Aktories, K. Alteration of the cytoskeleton of mammalian cells cultured in vitro by Clostridium botulinum $\mathrm{C} 2$ toxin and $\mathrm{C} 3$ ADP-ribosyltransferase. Eur. J. Cell Biol. 1991, 54, 237-245.

36. Schleberger, C.; Hochmann, H.; Barth, H.; Aktories, K.; Schulz, G.E. Structure and action of the binary C2 toxin from Clostridium botulinum. J. Mol. Biol. 2006, 364, 705-715.

37. Tsuge, H.; Nagahama, M.; Oda, M.; Iwamoto, S.; Utsunomiya, H.; Marquez, V.E.; Katunuma, N.; Nishizawa, M.; Sakurai, J. Structural basis of actin recognition and arginine ADP-ribosylation by Clostridium perfringens iota-toxin. Proc. Natl. Acad. Sci. USA 2008, 105, 7399-7404.

38. Wegner, A.; Aktories, K. ADP-ribosylated actin caps the barbed ends of actin filaments. J. Biol. Chem. 1988, 263, 13739-13742.

39. Schwan, C.; Stecher, B.; Tzivelekidis, T.; van Ham, M.; Rohde, M.; Hardt, W.D.; Wehland, J.; Aktories, K. Clostridium difficile toxin CDT induces formation of microtubule-based protrusions and increases adherence of bacteria. PLoS Pathog. 2009, 5, e1000626.

40. Schwan, C.; Kruppke, A.S.; Nölke, T.; Schumacher, L.; Koch-Nolte, F.; Kudryashev, M.; Stahlberg, H.; Aktories, K. Clostridium difficile toxin CDT hijacks microtubule organization and reroutes vesicle traffic to increase pathogen adherence. Proc. Natl. Acad. Sci. USA 2014, 111, 2313-2318.

41. Barth, H.; Blöcker, D.; Behlke, J.; Bergsma-Schutter, W.; Brisson, A.; Benz, R.; Aktories, K. Cellular uptake of Clostridium botulinum $\mathrm{C} 2$ toxin requires oligomerization and acidification. J. Biol. Chem. 2000, 275, 18704-18711.

42. Blöcker, D.; Behlke, J.; Aktories, K.; Barth, H. Cellular uptake of the binary Clostridium perfringens iota-toxin. Infect. Immun. 2001, 69, 2980-2987.

43. Stiles, B.G.; Hale, M.L.; Marvaud, J.C.; Popoff, M.R. Clostridium perfringens iota toxin: Binding studies and characterization of cell surface receptor by fluorescence-activated cytometry. Infect. Immun 2000, 68, 3475-3484.

44. Stiles, B.G.; Hale, M.L.; Marvaud, J.C.; Popoff, M.R. Clostridium perfringens iota toxin: Characterization of the cell-associated iota b complex. Biochem. J. 2002, 367, 801-808. 
45. Marvaud, J.C.; Stiles, B.G.; Chenal, A.; Gillet, D.; Gibert, M.; Smith, L.A.; Popoff, M.R. Clostridium perfringens iota toxin. Mapping of the Ia domain involved in docking with $\mathrm{Ib}$ and cellular internalization. J. Biol. Chem. 2002, 277, 43659-43666.

46. Nagahama, M.; Nagayasu, K.; Kobayashi, K.; Sakurai, J. Binding component of Clostridium perfringens iota-toxin induces endocytosis in Vero cells. Infect. Immun. 2002, 70, 1909-1914.

47. Nagahama, M.; Hagiyama, T.; Kojima, T.; Aoyanagi, K.; Takahashi, C.; Oda, M.; Sakaguchi, Y.; Oguma, K.; Sakurai, J. Binding and internalization of Clostridium botulinum C2 toxin. J. Infect Immun. 2009, 77, 5139-5148.

48. Blöcker, D.; Pohlmann, K.; Haug, G.; Bachmeyer, C.; Benz, R.; Aktories, K.; Barth, H. Clostridium botulinum $\mathrm{C} 2$ toxin: Low $\mathrm{pH}$-induced pore formation is required for translocation of the enzyme component C2I into the cytosol of host cells. J. Biol. Chem. 2003, 278, 37360-37367.

49. Gibert, M.; Marvaud, J.C.; Pereira, Y.; Hale, M.L.; Stiles, B.G.; Boquet, P.; Lamaze, C.; Popoff, M.R. Differential requirement for the translocation of clostridial binary toxins: Iota toxin requires a membrane potential gradient. FEBS Lett. 2007, 581, 1287-1296.

50. Schmid, A.; Benz, R.; Just, I.; Aktories, K. Interaction of Clostridium botulinum C2 toxin with lipid bilayer membranes. Formation of cation-selective channels and inhibition of channel function by chloroquine. J. Biol. Chem. 1994, 269, 16706-16711.

51. Bachmeyer, C.; Benz, R.; Barth, H.; Aktories, K.; Gilbert, M.; Popoff, M.R. Interaction of C2 toxin with lipid bilayer membranes and Vero cells: Inhibition of channel function by chloroquine and related compounds in vitro and intoxification in vivo. FASEB J. 2001, 15, 1658-1660.

52. Knapp, O.; Benz, R.; Gibert, M.; Marvaud, J.C.; Popoff, M.R. Interaction of the binding component of Clostridium perfringens iota-toxin with lipid bilayer membranes: Demonstration of channel formation by the activated binding component Ib and channel block by the enzyme component Ia. J. Biol. Chem. 2002, 277, 6143-6152.

53. Blöcker, D.; Bachmeyer, C.; Benz, R.; Aktories, K.; Barth, H. Channel formation by the binding component of Clostridium botulinum C2 toxin: Glutamate 307 of C2II affects channel properties in vitro and $\mathrm{pH}$-dependent $\mathrm{C} 2 \mathrm{I}$ translocation in vivo. Biochemistry 2003, 42, 5368-5377.

54. Lang, A.E.; Neumeyer, T.; Sun, J.; Collier, R.J.; Benz, R.; Aktories, K. Amino acid residues involved in membrane insertion and pore formation of Clostridium botulinum $\mathrm{C} 2$ toxin. Biochemistry 2008, 47, 8406-8413.

55. Haug, G.; Wilde, C.; Leemhuis, J.; Meyer, D.K.; Aktories, K.; Barth, H. Cellular uptake of Clostridium botulinum $\mathrm{C} 2$ toxin: Membrane translocation of a fusion toxin requires unfolding of its dihydrofolate reductase domain. Biochemistry 2003, 42, 15284-15291.

56. Krantz, B.A.; Finkelstein, A.; Collier, R.J. Protein translocation through the anthrax toxin transmembrane pore is driven by a proton gradient. J. Mol. Biol. 2006, 355, 968-979.

57. Haug, G.; Leemhuis, J.; Tiemann, D.; Meyer, D.K.; Aktories, K.; Barth, H. The host cell chaperone Hsp90 is essential for translocation of the binary Clostridium botulinum $\mathrm{C} 2$ toxin into the cytosol. J. Biol. Chem. 2003, 278, 32266-32274.

58. Kaiser, E.; Pust, S.; Kroll, C.; Barth, H. Cyclophilin A facilitates translocation of the Clostridium botulinum $\mathrm{C} 2$ toxin across membranes of acidified endosomes into the cytosol of mammalian cells. Cell. Microbiol. 2009, 11, 780-795. 
59. Haug, G.; Aktories, K.; Barth, H. The host cell chaperone Hsp90 is necessary for cytotoxic action of the binary iota-like toxins. Infect. Immun. 2004, 72, 3066-3068.

60. Nestorovich, E.M.; Bezrukov, S.M. Obstructing toxin pathways by targeted pore blockage. Chem. Rev. 2012, 112, 6388-6430.

61. Young, J.A.; Collier, R.J. Anthrax toxin: Receptor binding, internalization, pore formation, and translocation. Annu. Rev. Biochem. 2007, 76, 243-265.

62. Collier, R.J. Membrane translocation by anthrax toxin. Mol. Aspects Med. 2009, 30, 413-422.

63. Liu, S.; Moayeri, M.; Leppla, S.H. Anthrax lethal and edema toxins in anthrax pathogenesis. Trends Microbiol. 2014, doi:10.1016/j.tim.2014.02.012.

64. Bachmeyer, C.; Orlik, F.; Barth, H.; Aktories, K.; Benz, R. Mechanism of C2-toxin inhibition by fluphenazine and related compounds: Investigation of their binding kinetics to the C2II-channel using the current noise analysis. J. Mol. Biol. 2003, 333, 527-540.

65. Krantz, B.A.; Melnyk, R.A.; Zhang, S.; Juris, S.J.; Lacy, D.B.; Wu, Z.; Finkelstein, A.; Collier, R.J. A phenylalanine clamp catalyzes protein translocation through the anthrax toxin pore. Science 2005, 309, 777-781.

66. Neumeyer, T.; Schiffler, B.; Maier, E.; Lang, A.E.; Aktories, K.; Benz, R. Clostridium botulinum $\mathrm{C} 2$ toxin. Identification of the binding site for chloroquine and related compounds and influence of the binding site on properties of the C2II channel. J. Biol. Chem. 2008, 283, 3904-3914.

67. Beitzinger, C.; Bronnhuber, A.; Duscha, K.; Riedl, Z.; Huber-Lang, M.; Benz, R.; Hajós, G.; Barth, H. Designed azolopyridinium salts block protective antigen pores in vitro and protect cells from anthrax toxin. PLoS One 2013, 8, e66099.

68. Bronnhuber, A.; Maier, E.; Riedl, Z.; Hajós, G.; Benz, R.; Barth, H. Inhibitions of the translocation pore of Clostridium botulinum $\mathrm{C} 2$ toxin by tailored azolopyridinium salts protects human cells from intoxication. Toxicology 2014, 316, 25-33.

69. Karginov, V.A.; Nestorovich, E.M.; Moayeri, M.; Leppla, S.H.; Bezrukov, S.M. Blocking anthrax lethal toxin at the protective antigen channel by using structure-inspired drug design. Proc. Natl. Acad. Sci. USA 2005, 102, 15075-15080.

70. Karginov, V.A.; Nestorovich, E.M.; Yohannes, A.; Robinson, T.M.; Fahmi, N.E.; Schmidtmann, F.; Hecht, S.M.; Bezrukov, S.M. Search for cyclodextrin-based inhibitors of anthrax toxins: Synthesis, structural features, and relative activities. Antimicrob. Agents Chemother. 2006, 50, 3740-3753.

71. Karginov, V.A.; Yohannes, A.; Robinson, T.M.; Fahmi, N.E.; Alibek, K.; Hecht, S.M. Beta-cyclodextrin derivatives that inhibit anthrax lethal toxin. Bioorg. Med. Chem. 2006, 14, $33-40$.

72. Karginov, V.A.; Nestorovich, E.M.; Schmidtmann, F.; Robinson, T.M.; Yohannes, A.; Fahmi, N.E.; Bezrukov, S.M.; Hecht, S.M. Inhibition of S. aureus $\alpha$-hemolysin and B. anthracis lethal toxin by $\beta$-cyclodextrin derivatives. Bioorg. Med. Chem. 2007, 15, 5424-5431.

73. Díaz-Moscoso, A.; Méndez-Ardoy, A.; Ortega-Caballero, F.; Benito, J.M.; Ortiz Mellet, C.; Defaye, J.; Robinson, T.M.; Yohannes, A.; Karginov, V.A.; García Fernández, J.M. Symmetry complementarity-guided design of anthrax toxin inhibitors based on $\beta$-cyclodextrin: Synthesis and relative activities of face-selective functionalized polycationic clusters. ChemMedChem 2011, 6 , 181-192. 
74. Bezrukov, S.M.; Liu, X.; Karginov, V.A.; Wein, A.N.; Leppla, S.H.; Popoff, M.R.; Barth, H.; Nestorovich, E.M. Interactions of high-affinity cationic blockers with the translocation pores of B. anthracis, C. botulinum, and C. perfringens binary toxins. Biophys. J. 2012, 103, 1208-1217.

75. Nestorovich, E.M.; Karginov, V.A.; Berezhkovskii, A.M.; Bezrukov, S.M. Blockage of anthrax $\mathrm{PA}_{63}$ pore by a multicharged high-affinity toxin inhibitor. Biophys. J. 2010, 99, 134-143.

76. Nestorovich, E.M.; Karginov, V.A.; Popoff, M.R.; Bezrukov, S.M.; Barth, H. Tailored $\beta$-cyclodextrin blocks the translocation pores of binary exotoxins from $C$. botulinum and C. perfringens and protects cells from intoxication. PLoS One 2011, 6, e23927.

77. Nestorovich, E.M.; Karginov, V.A.; Berezhkovskii, A.M.; Parsegian, V.A.; Bezrukov, S.M. Kinetics and thermodynamics of binding reactions as exemplified by anthrax toxin channel blockage with a cationic cyclodextrin derivative. Proc. Natl. Acad. Sci. USA 2012, 109, 18453-18458.

78. Nestorovich, E.M.; Bezrukov, S.M. Designing inhibitors of anthrax toxin. Expert Opin. Drug Discov. 2014, 9, 299-318.

79. Moayeri, M.; Robinson, T.M.; Leppla, S.H.; Karginov, V.A. In vivo efficacy of $\beta$-cyclodextrin derivatives against anthrax lethal toxin. Antimicrob. Agents Chemother. 2008, 52, 2239-2241.

80. Perelle, S.; Scalzo, S.; Kochi, S.; Mock, M.; Popoff, M.R. Immunological and functional comparison between Clostridium perfringens iota toxin, C. spiroforme toxin, and anthrax toxins. FEMS Microbiol. Lett. 1997, 146, 117-121.

81. Sandvig, K.; Olsnes, S. Diphtheria toxin entry into cells is facilitated by low pH. J. Cell Biol. 1980, 87, 828-832.

82. Laemmli, U.K. Cleavage of structural proteins during the assembly of the head of bacteriophage T4. Nature 1970, 227, 680-685.

(C) 2014 by the authors; licensee MDPI, Basel, Switzerland. This article is an open access article distributed under the terms and conditions of the Creative Commons Attribution license (http://creativecommons.org/licenses/by/3.0/). 